\title{
Grazing pressure on coral reefs decreases across a wide depth gradient in the Gulf of Aqaba, Red Sea
}

\author{
Eran Brokovich ${ }^{1,2,3, *}$ Inbal Ayalon ${ }^{1,4}$, Shai Einbinder ${ }^{1,3}$, Nitzan Segev ${ }^{1,4}$, \\ Yonathan Shaked ${ }^{1,4}$ Amatzia Genin ${ }^{1,3,4}$, Salit Kark ${ }^{2}$, Moshe Kiflawi ${ }^{1,5}$ \\ ${ }^{1}$ The Interuniversity Institute for Marine Sciences at Eilat (IUI), PO Box 469, Eilat 88103, Israel \\ ${ }^{2}$ The Biodiversity Research Group, Department of Evolution, Systematics and Ecology, The Silberman Institute of Life \\ Sciences, The Hebrew University of Jerusalem, 91904, Israel \\ ${ }^{3}$ Department of Evolution, Systematics and Ecology, The Silberman Institute of Life Sciences, The Hebrew University \\ of Jerusalem, 91904, Israel \\ ${ }^{4}$ The Israel National Monitoring Program at the Gulf of Eilat, at the IUI \\ ${ }^{5}$ Department of Life Sciences, Ben Gurion University, PO Box 653, Beer-Sheva, 84105, Israel
}

\begin{abstract}
Algae are an essential component of healthy coral reefs and serve as the base of the food chain and as a living habitat for numerous organisms. Herbivorous fish play an important role in coral reef ecology by mediating competition between fast-growing algae and relatively slow-growing corals. However, because of diving-related difficulties, the importance of herbivory in deep mesophotic coral reefs $(30$ to $150 \mathrm{~m}$ ) remains largely unknown. We examined the relationship between herbivores and algae along a depth gradient down to $65 \mathrm{~m}$, and evaluated grazing pressure along the depth gradient. We visually assessed the abundance of herbivorous fish along the depth gradient and estimated fish biomass. We measured in situ turf algae growth rates and performed experimental assessments of grazing pressure using settlement plates and bioassays. We discovered that, while both algal growth and fish density decrease with depth, the decrease in grazing pressure is steeper, with a consumption of $<20 \%$ of turf-algae production at $65 \mathrm{~m}$ versus 40 to $60 \%$ at depths of 5 to $20 \mathrm{~m}$. Concomitantly, a decrease in fish biomass and density along the depth gradient reduced potential grazing pressure on macroalgae. Our findings suggest a less important role for herbivorous fish in maintaining algal-free substrate for coral recruitment and growth in deep zones compared with the shallow reef.
\end{abstract}

KEY WORDS: Depth gradient · Deep reefs · Gulf of Aqaba - Herbivore fish · Benthic algae Technical diving

Resale or republication not permitted without written consent of the publisher

\section{INTRODUCTION}

Algae communities are an essential component of any healthy coral reef, serving as the base of the food chain and as a living habitat for a myriad of organisms (Vroom et al. 2006). Algal growth is limited by a variety of factors (Albert et al. 2008), but mainly by nutrient load (bottom up process) and grazing pressure (topdown process) (Burkepile \& Hay 2006). Shallow reef algae are often inconspicuous due to a reduced canopy height which is kept low by grazing, yet they are often the major component of a 'coral' reef in terms of percentage cover (Vroom et al. 2006). Algae can outgrow corals when favorable conditions arise (Genin et al. 1995), and may also inhibit coral recruitment (McCook et al. 2001, Kuffner et al. 2006). Hence, grazers can be essential in controlling algal blooms during high nutrient loads (Burkepile \& Hay 2006), and thereby affect coral growth and survivorship.

By grazing on fast growing algae, herbivores play an important role in facilitating the settlement of corals and other sessile organisms onto coral reefs (Miller \& 
Hay 1998). Coral reef fishes have been identified as the primary grazers of macroalgae (Choat 1991). In locations where long term exploitation of herbivorous fish has led to algal takeover and the collapse of coral reef habitats (Jackson et al. 2001), the potential for rehabilitation is largely dependent on the re-establishment of herbivore populations (Hughes et al. 2007, but see Ledlie et al. 2007). Herbivores not only reduce the density and the biomass of algae, they also have a profound effect on algal community structure, species richness and dynamics (Hixon \& Brostoff 1996, Gobler et al. 2006). They were also found to promote algal productivity by either reducing algal self-shading or by the input of regenerated nutrient excretions (Carpenter 1986).

Different species and groups of algae are able to endure and even flourish to depths of 150 and even $260 \mathrm{~m}$ (Agegian \& Abbott 1985, Littler et al. 1985, Hillis-Colinvaux 1986, Aponte \& Ballantine 2001). Little is known about the physiology of algae in deep reefs, but as light diminishes so do algal growth rates (Markager \& Sand-Jensen 1992). Algae species numbers have also been found to decrease with depth (Gilmartin 1960). However, algal abundance (expressed in percentage cover) increases with depth; a fact attributed to low grazing levels (Van den Hoek et al. 1978, Liddell \& Sharon 1988, Morrison 1988) and, in some locations, to nutrient input from deeper water (Lesser et al. 2009). Herbivorous fish biomass was found to decrease with decreasing algal production (Russ 2003). As photosynthetic radiation and algal primary productivity decrease steeply with depth, herbivore abundance is expected to decrease with depth as well. Such a decrease in herbivore abundance was observed in 2 quantitative surveys of mesophotic fishes (Colin et al. 1986, Brokovich et al. 2008), accompanied by a decrease in species richness.

To date, depth gradients used to examine the interaction between algae and herbivores in coral reefs were largely limited to depths of no more than 20 m (Morrison 1988, Fox \& Bellwood 2007). Little is known of such interactions in mesophotic coral reef ecosystems (MCE; Lesser et al. 2009) which span a depth range of 30 to $150 \mathrm{~m}$; the aim of the present study was to extend our knowledge down to depths of $65 \mathrm{~m}$. Specifically, we examined how each of the following change along a 5 to $65 \mathrm{~m}$ depth gradient: (1) the density and bio- mass of herbivorous fish, (2) grazing pressure, and (3) algae growth potential. Note that we use the term 'herbivorous' in reference to fish capable of removing algal biomass from the reef surface (for a debate surrounding the use of the term see Clements et al. 2009).

\section{MATERIALS AND METHODS}

Study area. The Gulf of Aqaba, a northeastern extension of the Red Sea, harbors the northernmost coral reefs in the Indian Ocean (Veron 2000). This area is characterized by a fringing reef, steeply sloping to depths of ca. $150 \mathrm{~m}$ (Fricke \& Schumacher 1983). The study area, located $8 \mathrm{~km}$ south of the city of Eilat (Fig. 1), is characterized by a relatively continuous coral reef from 0.5 to $\sim 65-70 \mathrm{~m}$, at which point the slope becomes moderate with a mostly sandy bottom until $90 \mathrm{~m}$, where it plunges to deeper waters (E. Brokovich \& S. Einbinder pers. obs.).

Cover of hard substrate by turf algae in the shallow section of the study area varies between 0 and $70 \%$, depending on habitat and season (Benayahu \& Loya 1977). The algae community composition is diverse (Benayahu \& Loya 1977, Ateweberhan et al. 2006) and

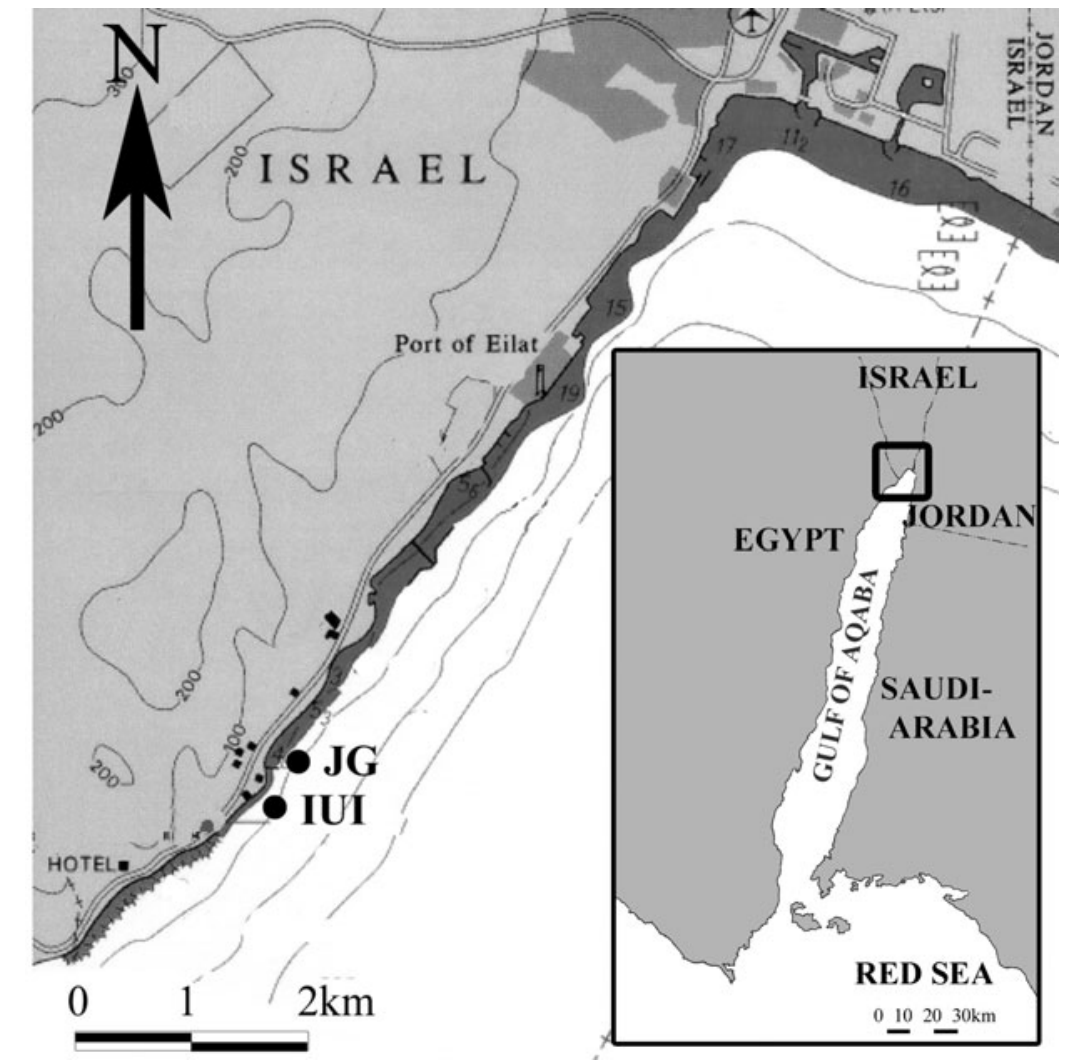

Fig. 1. Study sites. The northern Gulf of Aqaba with the 2 study sites. JG: Japanese Gardens; IUI: the Interuniversity Institute for Marine Sciences at Eilat 
oscillates with seasonal changes in nutrient levels. In the summer there is a steady thermocline at $\sim 150$ to $200 \mathrm{~m}$ and the upper water mass is nutrient depleted. In winter there is a deep vertical mixing of the water column creating an upwelling of nutrients from the deep (Genin et al. 1995, Lindell \& Post 1995, Shaked \& Genin 2009). In the times between these 2 states the coral reef between 0 and $65 \mathrm{~m}$ sees similar nutrient loads along the depth gradient, although some lagging between depths may be noticed (Lindell \& Post 1995). During numerous deep dives at the area (Brokovich et al. 2008) we observed abundant algal communities covering all exposed rock substratum from $40 \mathrm{~m}$ down to at least $70 \mathrm{~m}$ (E. Brokovich \& S. Einbinder unpubl. data).

The density of herbivorous fish in the shallow reefs of the northern Gulf of Aqaba ranges from 9 to 56 ind. $\mathrm{m}^{-2}$, depending on location and depth (Khalaf \& Kochzius 2002, Brokovich et al. 2008); in our sites the density seems to be at the lower side of this scale (Brokovich et al. 2008). These numbers are comparable to other locations in the western Indo-Pacific, where density ranges from 13 to $44 \mathrm{ind} . \mathrm{m}^{-2}$ for the 2 most abundant herbivorous families (i.e. Scaridae and Acanthuridae; McClanahan et al. 1999a, McClanahan et al. 1999b, McClanahan et al. 2001).

We conducted the fish census and grazing experiments along a depth gradient extending from 1 to $65 \mathrm{~m}$ in front of the Interuniversity Institute for Marine Sciences at Eilat (IUI), and at a second site known as the 'Japanese Gardens' located $400 \mathrm{~m}$ north of the IUI (Fig. 1). For the deep dives (below $20 \mathrm{~m}$ ) we used Megalodon closed circuit rebreathers (Innerspace Systems).

Fish density and biomass. Herbivorous fish bathymetric distribution and density were visually estimated following Brokovich et al. (2008). Fifty-two surveys were conducted along $25 \times 2 \mathrm{~m}$ transects at the following depths: 1, 5, 10, 20, 30, 50 and $65 \mathrm{~m}$ (Table 1). The maximum dive duration at depth set the above limit for length of transects. Fish were assigned as herbivores based on Randall (1983), Khalaf \& Disi (1997) and personal observations of feeding behavior. As such, the term herbivore herein refers to the removal of plant material from the reef, and not on the ability for actual consumption and digestion of plant material (Choat et al. 2004). Fish were identified to species level and their total length was visually estimated to the nearest centimeter (Brokovich et al. 2007). All census transects were done by the same person (E. Brokovich) between 2006 and 2008.

Fish biomass was determined based on speciesspecific length-to-weight (L-W) conversion parameters provided in Fishbase (Froese \& Pauly 2007). For species with no available L-W information we used the
Table 1. Study design. The number of replicates in each of the research components: fish survey transects, macroalgae bioassay, biomass growth experiment and chlorophyll experiment

\begin{tabular}{|lcccc|}
\hline $\begin{array}{l}\text { Depth } \\
(\mathrm{m})\end{array}$ & $\begin{array}{c}\text { Fish } \\
\text { transects } \\
\text { density \& } \\
\text { biomass }\end{array}$ & $\begin{array}{c}\text { Macro- } \\
\text { algae } \\
\text { bioassay }\end{array}$ & $\begin{array}{c}\text { Turf algae } \\
\text { biomass } \\
\text { (new } \\
\text { plates) }\end{array}$ & $\begin{array}{c}\text { Turf algae } \\
\text { biomass } \\
\text { (preconditioned } \\
\text { plates) }\end{array}$ \\
\hline 1 & 4 & 7 & 2 & 0 \\
5 & 6 & 8 & 4 & 0 \\
10 & 6 & 7 & 0 & 6 \\
20 & 7 & 11 & 4 & 0 \\
30 & 10 & 0 & 0 & 6 \\
35 & 0 & 11 & 0 & 0 \\
50 & 12 & 5 & 4 & 3 \\
65 & 7 & 9 & 4 & 0 \\
\hline
\end{tabular}

average parameter values for their genus. These estimates are the best available without collecting fish from the water. However, they are limited and must be considered as coarse estimates of the true biomass.

Herbivore pressure and algae growth. To evaluate the effect of herbivores (in general) on turf algae along the gradient, we conducted 2 experiments in which we measured algal growth on caged and exposed plates. Algal biomass accumulation on the grazing-free caged plates was used to estimate potential growth, while the difference in algal biomass between the caged and exposed plates provided a proxy for grazing pressure (Smith et al. 2001). For both experiments, we used $10 \times$ $10 \mathrm{~cm}$ PVC settlement plates placed at different depths; these were placed in pairs of exposed and wire-mesh caged plates (mesh size $12 \times 12 \mathrm{~mm}$, wire diameter $1 \mathrm{~mm}$; Fig. 2). The 2 experiments are outlined below.

(1) Biomass growth experiment: We placed exposed settlement plates, 12 at a depth of $10 \mathrm{~m}, 12$ at $30 \mathrm{~m}$, and 6 at $50 \mathrm{~m}$ next to the reef in front of the IUI. The plates

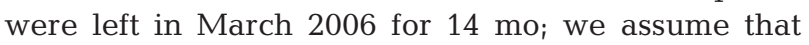
after such a long period the algae on these 'preconditioned plates' would be in a steady state of growth and grazing. In May 2007, we caged half of the plates for an additional 4 mo (Fig. 2). At the end of that period we retrieved the plates, scraped them using a plastic scraper, dried the algal material in an oven at $65^{\circ} \mathrm{C}$ for $24 \mathrm{~h}$ and weighed it, burned the material in a muffle furnace at $450^{\circ} \mathrm{C}$ and weighed it again, and calculated the ash free dry weight (AFDW).

Assuming that algal growth in the covered plates proceeded linearly at a constant rate $(g)$, and that algal biomass in the exposed plates was at steady state, we estimated algal consumption rate as: consumption rate $(c)=$ growth rate $(g)=\Delta A / t$. $\Delta A$ is the difference in biomass between the covered and exposed plates $\left(A_{\mathrm{c}}\right.$ and $A_{0}$, respectively) following the 4 mo period ( $t$, mea- 


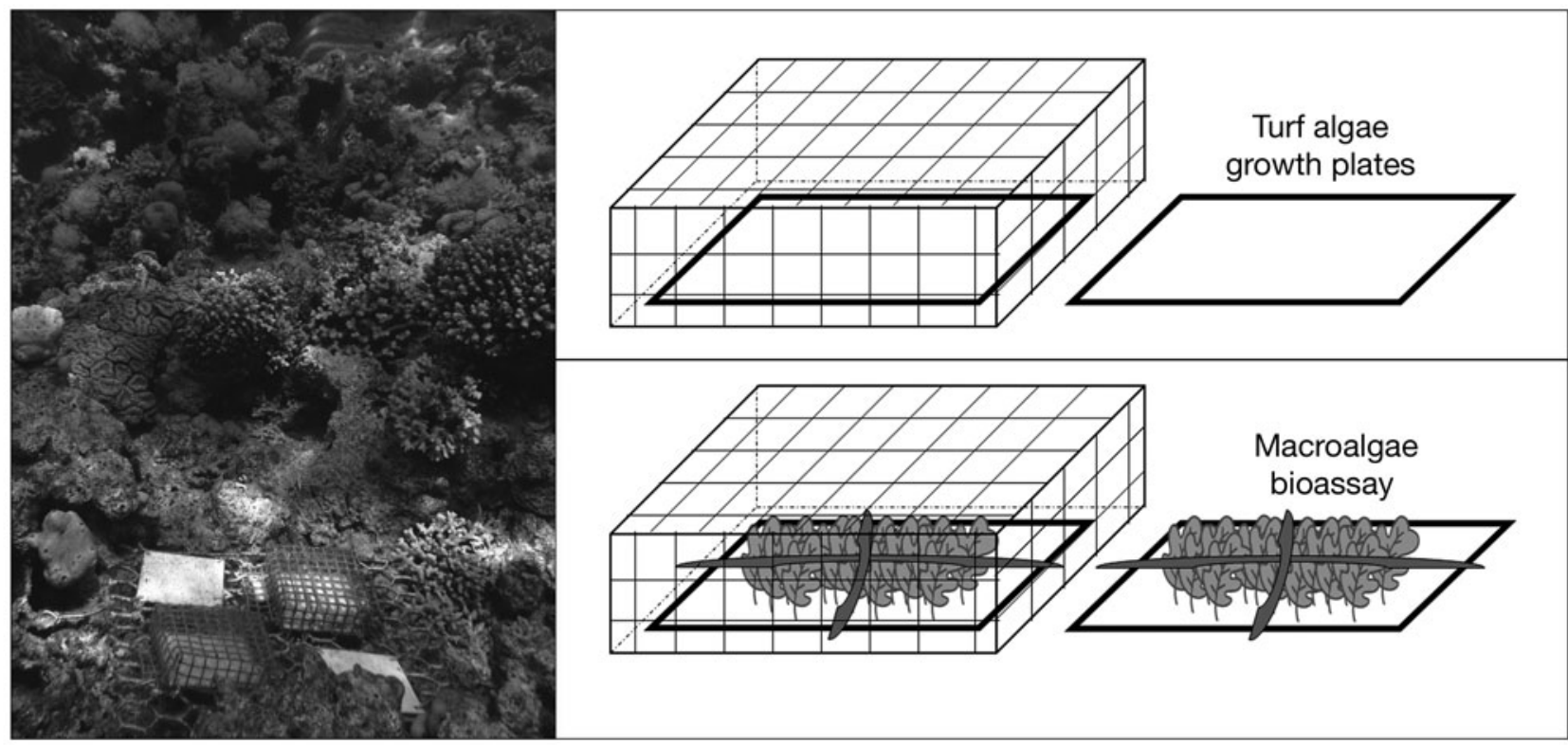

Fig. 2. Caged vs. exposed settlement plates (top right), macroalgae bioassay (bottom right) and experimental pairs in the reef (left)

sured in days). Our estimate of the consumption rate is likely to underestimate the true value, as cropped algae grow faster than when left undisturbed (Cooper 1973). The assumption of linear growth is supported by the linear increase in chlorophyll a concentrations (measured at 1 mo intervals over $5 \mathrm{mo}$ ) for turf algae grown on caged settlement plates at $10 \mathrm{~m}$ depth (Genin \& Silverman 2003). In addition, we calculated the 'relative consumption' of algal biomass $\left(A_{\mathrm{r}}=\Delta \mathrm{A} /\right.$ $A_{\mathrm{C}}$ ), as an index of herbivore ability to mitigate algal accumulation (i.e. the proportion of algal growth potential which is removed by herbivory).

In January 2007, 2 non-preconditioned pairs of caged and uncaged plates were placed in the Japanese Gardens at depths of 5, 20,50, and $65 \mathrm{~m}$, and 2 pairs were additionally placed at 1, 5, 20, 50 and $65 \mathrm{~m}$ in April 2007. After 2 mo of submersion, we removed these plates and calculated $A_{\mathrm{r}}$. Since we do not know the date of algal settlement on these plates, and as the exposed plates are unlikely to have reached steadystate, we were unable to estimate growth and consumption rates. Instead we calculated the relative accumulation of algae as $A_{\mathrm{C}} / A_{\mathrm{c} \text {-max }}$, where $A_{\mathrm{c} \text {-max }}$ is the maximum biomass on a caged plate at a given point in time.

In the deep habitats (50 and $65 \mathrm{~m}$ ) we occasionally noticed higher algal biomass on the exposed plates. This probably resulted from reduced growth owing to limited light in the deeper waters, which was made worse by the effect of the cage. A similar discrepancy was encountered in areas with high sedimentation (1 $\mathrm{m}$ depth in the lagoon), with caged plates accumu- lating more sediment. In these instances we set the difference in biomass to zero. A control experiment using half caged plates would have been helpful in determining the cage effect. However, it was not used as former studies in shallow habitats showed very little effect of the mesh (Carpenter 1986, Hixon \& Brostoff 1996, Miller et al. 1999). As it is possible that the mesh effect increases with diminishing light, it would be advisable to use this control in future studies.

(2) Chlorophyll experiment: We estimated algal consumption using chlorophyll a as a proxy of algal biomass, extending the depth range of the long-term monitoring of algal grazing by the Israel National Monitoring Program (NMP) in the Gulf of Eilat (Shaked \& Genin 2009). Six pairs of settlement plates were placed in the Japanese Gardens, at depths of 1, 5, 20, 50 and $65 \mathrm{~m}$. As before, each pair consisted of 1 exposed and 1 caged plate. Once a month, over a period of $1 \mathrm{yr}$, we removed and replaced 3 pairs of plates, which had been immersed for 2 mo. As chlorophyll concentrations can change both seasonally and with depth, grazing pressure at each depth was estimated by the difference in concentrations (caged minus exposed), expressed as a percentage of the concentration of the caged plate. Estimates were obtained for each pair, and averaged for each depth. The cages at 50 and $65 \mathrm{~m}$ were modified and had a mesh made from transparent fishing net to reduce shading effect.

Once taken out of the water, each plate was thoroughly scraped and washed over a $47 \mathrm{~mm}$ GF/A filter (Whatman) using a vacuum filtration system. Follow- 
ing filtration, the filter was placed in a vial with $30 \mathrm{ml}$ of 50/50 (v/v) acetone and methanol mixture. After $24 \mathrm{~h}$ of dark incubation at $4^{\circ} \mathrm{C}, 1 \mathrm{ml}$ from each vial was read in a spectrophotometer (Ultrospec 2100 pro, GE Healthcare) to calculate the concentration of chlorophyll $a$, as described by Parsons et al. (1984). To evaluate the accuracy of chlorophyll a based estimates of biomass, we compared the monthly average concentration with the results of the biomass experiment for that same time period (January and April 2007).

To assess algal physiological performance in situ, we measured chlorophyll fluorescence of clumps of turf algae using an underwater pulse amplitude modulated fluorometer (Diving-PAM, Walz). On a cloudless day in December 2008, we generated rapid light curves (RLC, or rapid P-I curves: see Ralph and Gademann 2005) for 3 to 4 turf algae clumps at the following 9 depths: 1.5 , $6,11,16,21,25,30,35$ and $41 \mathrm{~m}$. Ambient photosynthetically active radiation (PAR) was measured using the Diving-PAM's external quantum sensor (calibrated against the LI-190 LI-COR quantum sensor); this was used to calculate the attenuation coefficient $(k d)$. Each algae clump was irradiated with increasing PAR in pre-set steps $(0,14,57,124,233,365,521,794$ and $1102 \mu \mathrm{mol}$ photons $\mathrm{m}^{-2} \mathrm{~s}^{-1}$ ) for $5 \mathrm{~s}$, and the effective quantum yield of photosystem II $(Y)$ was recorded after each step. Relative electron transport rates (rETR) were calculated by multiplying $Y$ with PAR and with 0.5 (Beer et al. 1998); rETR on PAR curves were generated, and the maximum phosynthetic capacity $\left(P_{\max }\right)$ was determined using the equation of Platt et al. (1980) by means of an iterative non-linear regression program in SigmaPlot 10 (SPSS). As the species composition of the algal clumps is unknown, variation in PAM readings should be interpreted with caution

Assessing macroalgae consumption (by fish). To further assess how grazing pressure varies with depth, we conducted the following bioassay experiment. Aliquots of $20 \mathrm{~g}$ of Ulva sp. were tied by rubber bands to $10 \times 10 \mathrm{~cm}$ PVC plates. Experimental units consisted of 1 predator-exclusion mesh-caged plate (mesh size: $12 \times 12 \mathrm{~mm}$ ) and 1 exposed plate (Fig. 2). At least 5 replicates were placed at each depth $(1,5$, $10,20,35,50$ and $65 \mathrm{~m}$ ) during July 2007, September 2007 and January 2008 (Table 1). Depending on depth, plates were left for 1.5 to $14.5 \mathrm{~h}$ after which the algae was removed, dried at $60^{\circ} \mathrm{C}$ for $24 \mathrm{~h}$ and weighed. Preliminary experiments were conducted to establish the time intervals needed at each depth to ensure that the plates were removed before the Ulva was completely consumed. To quantify the amount of algae consumed, the weight of the exposed algae was subtracted from the weight of the caged algae and then divided by submersion time. Given the relatively short exposure-time of the plates, we feel it is safe to assume that any inferred herbivory is attributable to fish.

Data analysis. Depth-related differences in herbivore species composition were evaluated with groupaverage cluster analysis using Bray-Curtis similarity on 4th root transformed data (PRIMER-E). Changes in herbivore species richness along the depth gradient were evaluated using rarefaction to control for differences in sampling effort (i.e. in the total number of individuals encountered at each depth). Sample-based accumulation curves were generated using EstimateS (Colwell 2005), and the number of species was plotted as a function of the accumulated number of individuals (Gotelli \& Colwell 2001).

Quantile regression (StataCorp) was used to examine depth related gradients in Ulva consumption rates, relative consumption of turf algae, fish biomass and fish abundance. Quantile regression can be used to model the relationship between the independent variable $(x)$ and the upper boundary of the conditional (on $x)$ distribution of the response variable; it is especially informative given heterogeneous variances (Cade \& Noon 2003). This relationship describes the maximally attainable values of the response variable, as dictated by the putatively limiting effect of $x$. Heterogeneous variation under the boundary is taken to result from interaction with other unmeasured variables that can further limit the response; note that additive (rather than interactive) effects of additional, unmeasured, limiting factors are expected to produce homogeneous variances and consequent homogeneity in the slopes of successive quantiles. Note that a quantile regression of the 50th quantile is equivalent to a linear least absolute deviation (LAD) regression model of the conditional medians, and is an alternative to ordinary least squares (OLS) modeling of the central tendency (Cade et al. 1999).

We fitted 2 models to each of the 4 response variables: $\ln (y)=b_{0}-\left(b_{1} \times\right.$ depth $)$ and $\ln (y)=b_{0}-\left[b_{1} \times\right.$ $\ln ($ depth)]. Model performance was then compared using small-sample Akaike's information criterion (AIC) values, calculated using the sum of weighted absolute deviations (e.g. Pacheco et al. 2005). As both models had similar AIC values for all 4 response variables (not shown), we chose the exponential model to describe our data. This enabled us to examine the slopes of the 4 response variables with reference to the exponential attenuation of light with depth. Importantly, in comparing slopes we do not aim to test hypotheses regarding the factors that limit algal growth or fish biomass/abundance, but simply to compare rates of change. In the case of fish biomass/abundance, it is important to remember that these are not measures of 'carrying capa-

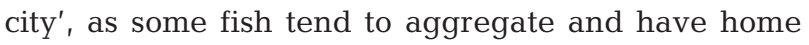
ranges that extend beyond our transect areas. 
Algal growth and consumption rates between 10, 30 and $50 \mathrm{~m}$, as well as relative consumption and biomass on the exposed plates, were compared by 1-way ANOVA with Fisher's post-hoc tests using the program STATISTICA (StatSoft). ANOVA assumptions were tested; in cases where they were violated, we used Kruskal-Wallis nonparametric test with multiple comparisons.

Caveat. We did not observe any sea urchins deeper than $30 \mathrm{~m}$, and did not observe micrograzers such as mollusks or amphipods at any depth. However, as we did not dive at night we cannot rule out their effect. As such, turf algae consumption relates to the effect of all herbivores and not only fish.

\section{RESULTS}

\section{Fish assemblage structure}

Overall, we found 21 species of herbivorous reef fish, belonging to 6 families (Table 2). Members of the Scaridae, Acanthuridae and Siganidae were characterized by large roving herbivores; those of the Blenniidae, Pomacanthidae and Pomacentridae were characterized by smaller, site-attached herbivores (Table 2). Cluster analysis suggests that the species assemblage in the deep reef (50 to $65 \mathrm{~m}$ ) is highly dissimilar from that found between 5 and $30 \mathrm{~m}$ (Fig. 3). Species rich- ness per sampling effort was highest at $30 \mathrm{~m}$, and lowest at $65 \mathrm{~m}$ where richness appears to asymptote at a relatively low sampling effort (Fig. 4). Four of the 6 species reaching the deep reef (50 to $65 \mathrm{~m}$ ) were scarids (Table 2), usually large, single individuals (>30 cm). Except for Calotomus viridescens, no juveniles were seen deeper than $30 \mathrm{~m}$.

Both biomass and density of herbivorous fishes peaked at $1 \mathrm{~m}$ depth, with a maximum of $>200$ ind. (mean: $111 \pm 30 \mathrm{SE}$ ) and $20 \mathrm{~kg} 100 \mathrm{~m}^{-2}$ (mean: $11.07 \pm$ $3.27 \mathrm{SE}$ ). From there, the upper percentiles of both

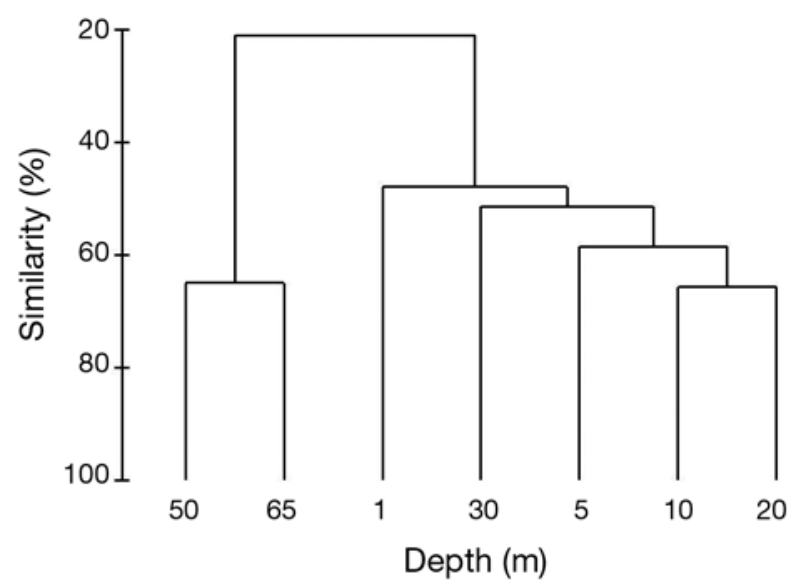

Fig. 3. Dendrogram depicting among depth Bray-Curtis similarity on 4th root transformed density of herbivorous fish species, with data pooled across the 3 study sites

Table 2. Occurrence of herbivorous fish along the depth gradient. (+) denotes species seen at least once; s: site-attached fish; r: roving herbivores

\begin{tabular}{|c|c|c|c|c|c|c|c|c|c|}
\hline \multirow{2}{*}{ Family } & \multirow{2}{*}{ Species } & \multirow[b]{2}{*}{1} & \multirow[b]{2}{*}{5} & \multirow[b]{2}{*}{10} & \multirow{2}{*}{$\begin{array}{c}\text { Depth }(\mathrm{m}) \\
20\end{array}$} & \multirow[b]{2}{*}{30} & \multirow[b]{2}{*}{50} & \multirow[b]{2}{*}{65} & \multirow{2}{*}{ Group } \\
\hline & & & & & & & & & \\
\hline \multirow[t]{2}{*}{ Pomacanthidae } & Centropyge multispinis & & + & + & + & & & & $\mathrm{s}$ \\
\hline & Apolemichthys xanthotis & & & & & + & + & + & $\mathrm{s}$ \\
\hline Pomacentridae & Chrysiptera unimaculata & + & & & & & & & $\mathrm{s}$ \\
\hline \multirow[t]{8}{*}{ Scaridae } & Calotomus viridescens & & + & & & + & + & + & $\mathrm{r}$ \\
\hline & Cetoscarus bicolor & & & & & + & & & $\mathrm{r}$ \\
\hline & Chlorurus genazonatus & + & & & + & + & & & $\mathrm{r}$ \\
\hline & Chlorurus sordidus & + & + & + & + & + & & & $\mathrm{r}$ \\
\hline & Scarus ferrugineus & + & + & & + & & & + & $\mathrm{r}$ \\
\hline & Scarus fuscopurpureus & + & & & + & & + & + & $\mathrm{r}$ \\
\hline & Scarus niger & + & + & + & + & + & + & & $\mathrm{r}$ \\
\hline & Chlorurus gibbus & & + & & & + & & & $\mathrm{r}$ \\
\hline \multirow[t]{4}{*}{ Blenniidae } & Ecsenius aroni & & & & + & + & & & $\mathrm{s}$ \\
\hline & Ecsenius dentex & & + & & + & & & & $\mathrm{s}$ \\
\hline & Ecsenius frontalis & & + & + & + & + & & & $\mathrm{s}$ \\
\hline & Ecsenius gravieri & & & + & + & + & & & $\mathrm{s}$ \\
\hline \multirow[t]{3}{*}{ Siganidae } & Siganus argenteus & & + & & & & & & $\mathrm{r}$ \\
\hline & Siganus luridus & + & + & + & & + & + & & $\mathrm{r}$ \\
\hline & Siganus rivulatus & & + & & & & & & $\mathrm{r}$ \\
\hline \multirow[t]{3}{*}{ Acanthuridae } & Acanthurus nigrofuscus & + & + & + & + & & & & $\mathrm{r}$ \\
\hline & Ctenochaetus striatus & + & + & & + & + & & & $\mathrm{r}$ \\
\hline & Zebrasoma xanthurum & + & + & + & + & + & & & $\mathrm{r}$ \\
\hline
\end{tabular}


No. of individuals at 5 to $65 \mathrm{~m}$ depths

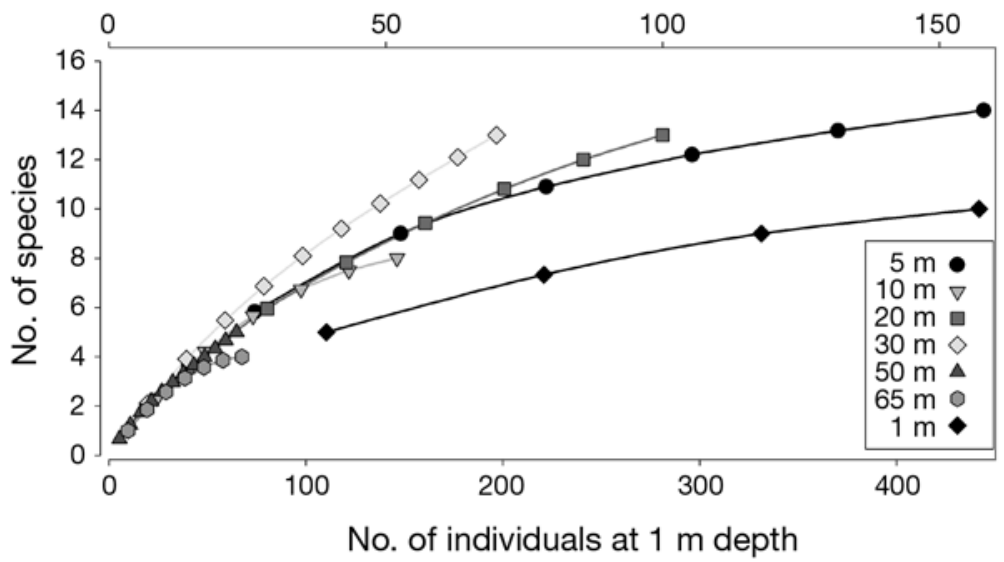

Fig. 4. Accumulation of species richness with sampling effort (number of individuals sampled) at different depths. For convenience, bottom axis is for the $1 \mathrm{~m}$ depth only; top axis is for all the other depths

variables decreased exponentially with depth, to a maximum of 10 ind. (mean: $3.4 \pm 1.36 \mathrm{SE}$ ) and $5 \mathrm{~kg}$ (mean: $1.79 \pm 0.86 \mathrm{SE}$ ) at $65 \mathrm{~m}$ (Fig. 5). Acanthuridae and Scaridae had the highest biomass, with up to $\sim 8 \mathrm{~kg} 100 \mathrm{~m}^{-2}$ for Acanthuridae at $1 \mathrm{~m}$, and over $4 \mathrm{~kg}$ $100 \mathrm{~m}^{-2}$ for Scaridae at $5 \mathrm{~m}$. Siganidae added $\sim 0.7 \mathrm{~kg}$ $100 \mathrm{~m}^{-2}$ at $5 \mathrm{~m}$, and the rest of the fish families added very little to the total biomass (Fig. 6). Acanthuridae were by far the most abundant fish in shallow water with an average of over 100 ind. $100 \mathrm{~m}^{-2}$. Scaridae averaged up to 5 ind. $100 \mathrm{~m}^{-2}$. Siganidae was recorded almost exclusively at $5 \mathrm{~m}$, and averaged $\sim 5$ ind. $100 \mathrm{~m}^{-2}$ at that depth. Site-attached herbivorous species were more abundant in intermediate depths of $\sim 20 \mathrm{~m}$, and reached a maximum of 9 ind. $100 \mathrm{~m}^{-2}$ at 20 m depth (Fig. 6).

Estimated rates of the exponential decrease with depth of the upper percentiles $(>80 \%$ ) of herbivore biomass fell within a relatively narrow range, although most estimates were not significantly different from zero. On the other hand, for the upper percentiles ( $>65 \%$ ) of herbivore abundance, estimated rates of decrease differed significantly from zero (Fig. 5, Table 3).

\section{Growth and consumption of turf algae}

The mean light attenuation coefficient calculated at the day of the PAM experiment in September 2008 was $0.105 \pm 0.004$ SE (Fig. 7A). Light attenuation coefficients for January and April 2007 were very similar (average of $0.107 \pm 0.006 \mathrm{SE}$ for the experimental duration). Surface light intensity directly below the water surface was stronger in April $(1550 \mu \mathrm{mol}$ photons $\left.\mathrm{m}^{-2} \mathrm{~s}^{-1} \pm 86 \mathrm{SE}\right)$ than in January $(1282 \mu \mathrm{mol}$ photons $\mathrm{m}^{-2} \mathrm{~s}^{-1} \pm 82 \mathrm{SE}$ ). The potential photosynthetic capacity decreased exponentially with depth, with a coefficient of $0.0436 \pm 0.008 \mathrm{SE}_{;} \mathrm{r}^{2}=0.86$; $\mathrm{p}<0.0001$ (Fig. 7B). Relative biomass accumulation of turf algae decreased with depth across the different quantiles. Quantiles $>50 \%$ decreased at a relatively constant rate, with a coefficient of $\sim 0.033$ (Fig. 7C, Table 3)

Algal consumption rate (assumed to equal the growth rate, $\Delta A / t$ ) in caged preconditioned plates decreased from $\sim 0.15 \mathrm{~g} \mathrm{~d}^{-1} \mathrm{~m}^{-2}$ AFDW at $10 \mathrm{~m}$ to $\sim 0.04 \mathrm{~g}$ $\mathrm{d}^{-1} \mathrm{~m}^{-2}$ at $30 \mathrm{~m}$, and down to $0 \mathrm{~g} \mathrm{~d}^{-1} \mathrm{~m}^{-2}$ at $50 \mathrm{~m}$ (1-way ANOVA, $\mathrm{p}<0.03$ : Fig. 8A). The (assumed) steady-state biomass of algae (AFDW) on the exposed preconditioned plates was on average almost 2-fold higher at $50 \mathrm{~m}$ than at $10 \mathrm{~m}$ depth $(17.84 \pm$ $5.34 \mathrm{SE}$ and $9.96 \pm 1.31 \mathrm{SE} \mathrm{g} \mathrm{d}^{-1} \mathrm{~m}^{-2}$, respectively). At $30 \mathrm{~m}$ we calculated an intermediate biomass of $14.72 \pm 1.40 \mathrm{SE} \mathrm{g} \mathrm{AFDW} \mathrm{d}{ }^{-1} \mathrm{~m}^{-2}$; although the difference was not statistically significant $(\mathrm{p}<$ 0.09). Relative consumption of turf algae $\left(A_{\mathrm{r}}\right)$ from the preconditioned plates averaged $59.98 \%$ at $10 \mathrm{~m}$,

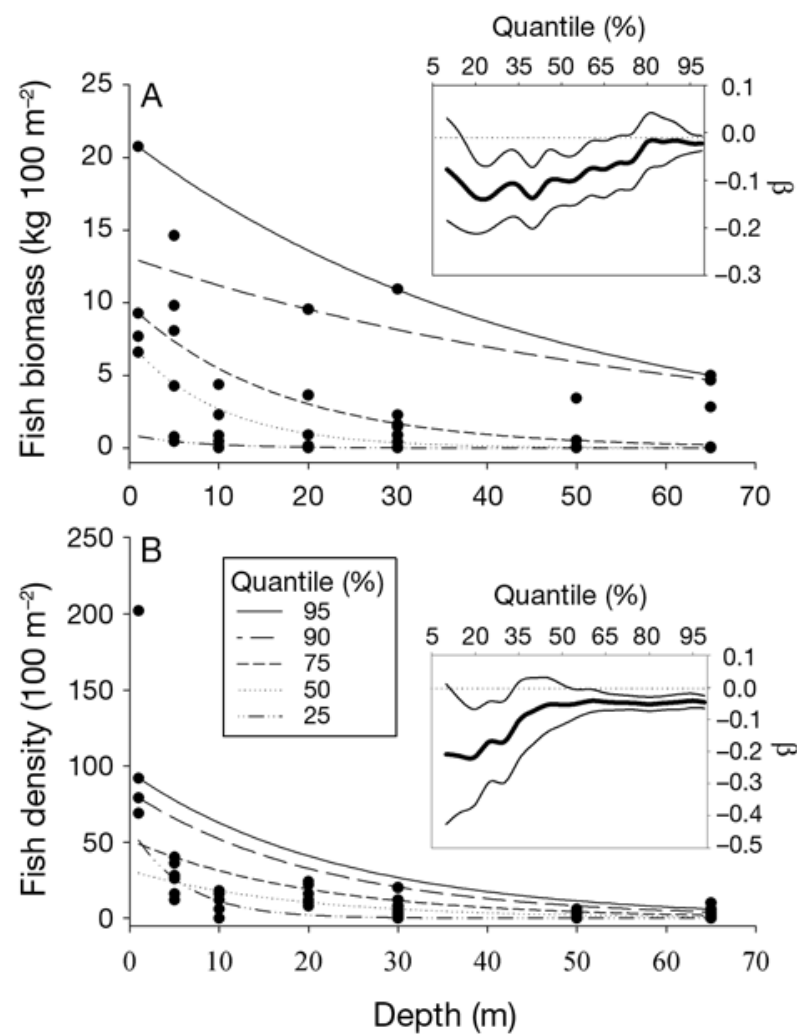

Fig. 5. Fish biomass (A) and density (B) along the depth gradient. Quantile regression lines depict expected values for the $25,50,75,90$ and 95th quantiles. Insets show the change in the exponential decay rate $(\beta)$ as a function of the different quantiles, along with $95 \%$ confidence intervals 


\section{A Biomass $\left(\mathrm{kg} \mathrm{m}^{-2}\right)$}

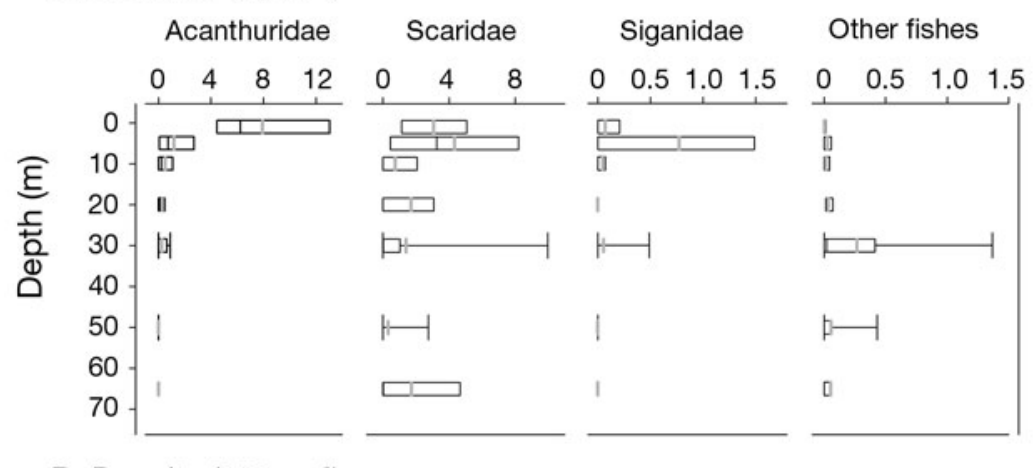

B Density $\left(100 \mathrm{~m}^{-2}\right)$

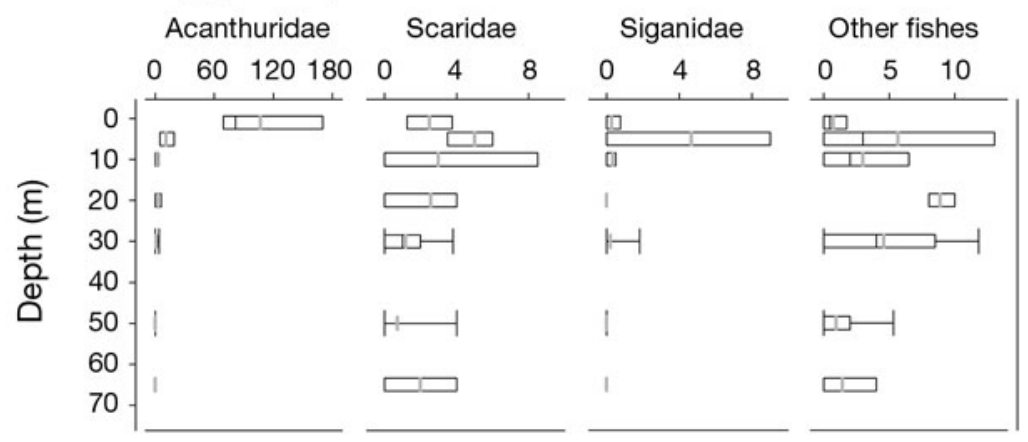

Fig. 6. (A) Biomass and (B) density distribution along the depth gradient for the main families of herbivorous fish. Box plots represent 25,50 and 75th quantiles. Grey line represents the mean. Error bars represent the 10th and 90th quantiles

Table 3. Slope coefficients of 75 and $95 \%$ quantile regression lines $\left(Q=a \times e^{-\beta \text { depth }}\right)$ along the depth gradient

\begin{tabular}{|lcc|}
\hline Parameter & $\begin{array}{c}75 \% \\
\text { quantile's } \beta\end{array}$ & $\begin{array}{c}95 \% \\
\text { quantile's } \beta\end{array}$ \\
\hline Fish biomass & 0.059 & 0.022 \\
Fish density & 0.05 & 0.043 \\
Algal relative accumulation & 0.033 & 0.0282 \\
Ulva consumption & 0.049 & 0.051 \\
$P_{\max }$ & 0.043 & 0.039 \\
\hline
\end{tabular}

$18.83 \%$ at $30 \mathrm{~m}$ and $0 \%$ at $50 \mathrm{~m}$ depth (ANOVA, $\mathrm{p}=$ 0.043, Fig. 8A).

Algal biomass on exposed unconditioned plates were significantly different between depths (1-way ANOVA, $\mathrm{p}<0.05)$; post hoc tests showed that the algae biomass at $1 \mathrm{~m}$ depth was higher than the other depths, and the biomass at $5 \mathrm{~m}$ depth was higher than at $65 \mathrm{~m}$ $(\mathrm{p}<0.02)$.

Relative consumption $\left(A_{\mathrm{r}}\right)$ was highest between depths of 5 to $20 \mathrm{~m}$, ranging from 40 to $60 \%$ compared with $<20 \%$ at the deep reef (Fig. 8C). Similarly, significant differences were obtained using either biomass or chlorophyll data (Kruskal-Wallis ANOVA, p < 0.001: Fig. 8C)

\section{Macroalgae consumption}

The amount of macroalgae consumed decreased with depth, with a decay coefficient of $\sim 0.05$ for all quantiles higher than $50 \%$ (Fig. 8B, Table 3). The average amount consumed (from a maximum of $\sim 27 \mathrm{~g}$ dry wt in the shallow water to a minimum of $0 \mathrm{~g}$ dry wt at $65 \mathrm{~m}$ ) was positively correlated with average total biomass of herbivorous fish (Pearson, $\mathrm{r}^{2}=$ 0.92, Table 4). At the family level, the positive correlation between fish biomass and the amount of macroalgae consumed was statistically significant for the Acanthuridae, but not for the Scaridae (Table 4).

\section{DISCUSSION}

The biomass of grazing fish on coral reefs is known to correlate positively with turf-algae production rates (Russ 2003). Also, the abundance of non-crustose algae was shown to increase with depth and with the reduction in grazing intensity (Van den Hoek et al. 1978, Carpenter 1986, Morrison 1988). We found that both the density and biomass of herbivorous fish peaked in very shallow water (1 to $5 \mathrm{~m}$ ) and rapidly decreased with depth, along with light intensity, photosynthetic capacity and relative algal productivity. Interestingly however, we found that 'grazing pressure' (proxied by our measures of the consumption rates of turf-algae and Ulva, and by our index of relative consumption: $A_{\mathrm{r}}$ ) also decreased with depth. This decrease appears to result from the differential rate of decrease in herbivore presence and algal production with depth (Table 3). As a result, algal biomass at steady state (to the extent that one can talk of a seasonally varying steady state) can be higher at greater depths, despite lower growth rate and photosynthetic capacity.

Herbivore impact on algal accumulation in mesophotic reefs may thus be substantially lower than their impact at shallow reefs. The ecological implications of this eventuality are currently unclear, in part because the reasons for the observed depth-related decrease in herbivore density and biomass are equally unclear. The decrease in relative consumption with depth, and the decrease in consumption rate normalized to fish biomass (from $\sim 5$ to $10 \mathrm{~m}$, Fig. 8A,C), suggest that algal availability in itself is not the reason; especially as substratum availability for algal growth increased with depth (Brokovich et al. 2008). 


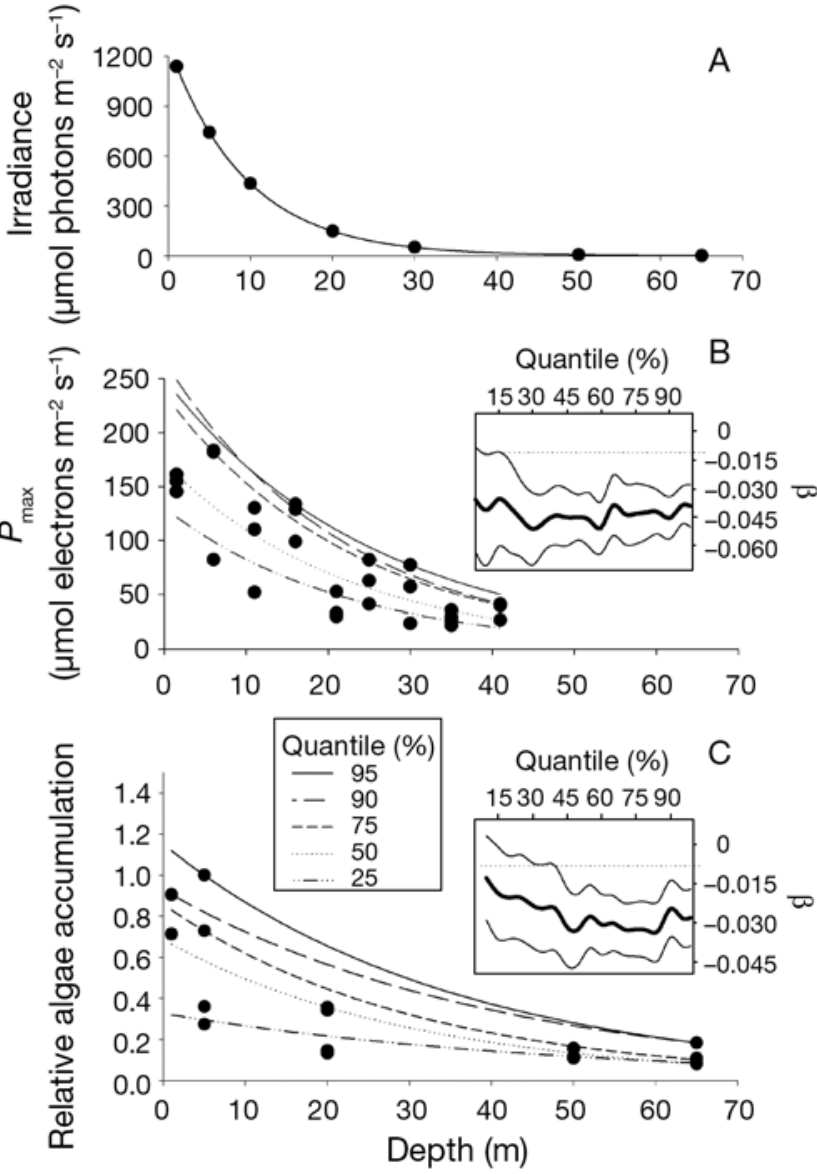

Fig. 7. Changes along the depth gradient in (A) light intensity with depth, (B) photosynthesis capacity, and (C) relative algae accumulation (short term experiment). Details as in Fig. 5
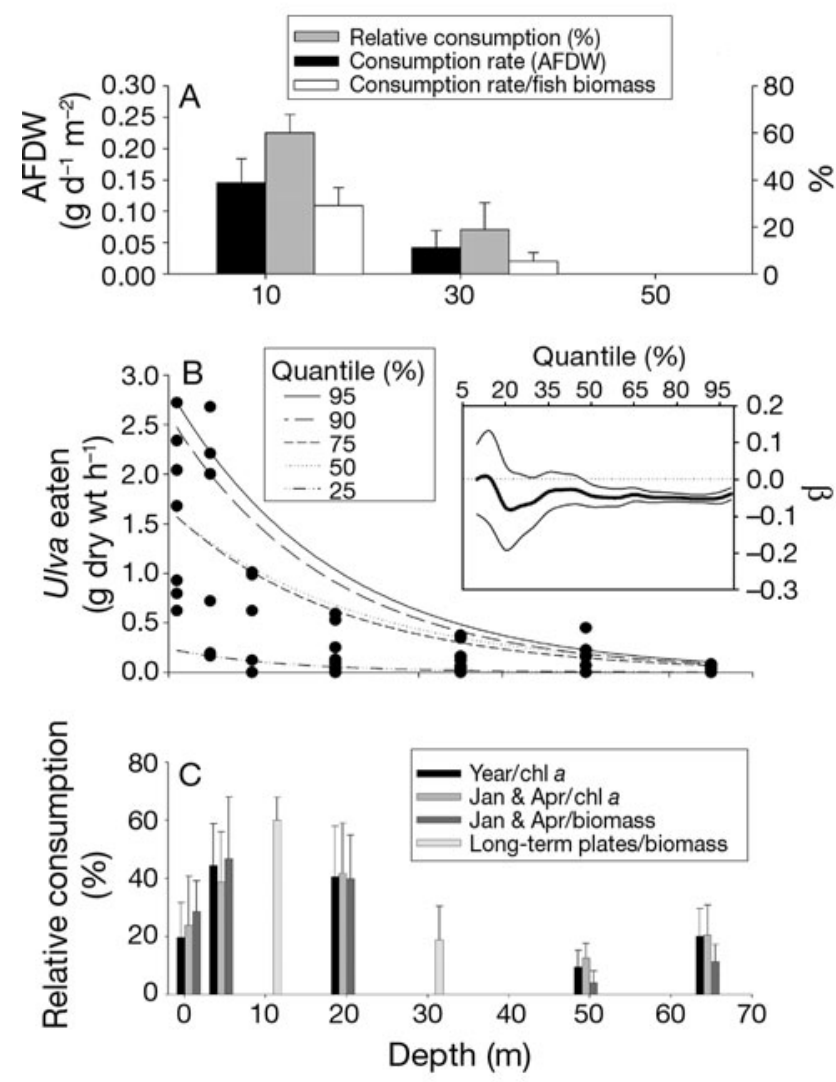

Fig. 8. (A) Turf-algae consumption rate, relative consumption and consumption normalized to fish biomass at the 3 depths examined in the long-term experiments. (B) The decrease with depth in macroalgae consumption rates (details as in Fig. 5). (C) Relative consumption of turf algae in long- and short-term experiments, based on both biomass and chlorophyll a measurements. Error bars show SE. AFDW: ash free dry weight

Table 4. Linear correlations between means of fish biomass/density (total and different families) and Ulva algae consumption (mg dry wt $\mathrm{h}^{-1}$ ), relative algal biomass accumulation and grazing pressure (calculated as the percentage of algae consumed from algae growth in paired plates). ${ }^{*} \mathrm{p}<0.05 ;{ }^{* *} \mathrm{p}<0.01 ;{ }^{* * *} \mathrm{p}<0.001$

\begin{tabular}{|c|c|c|c|c|c|c|c|c|c|c|c|}
\hline & \multirow[b]{2}{*}{ Total } & \multirow[b]{2}{*}{$\begin{array}{l}\text { Acanthu- } \\
\text { ridae }\end{array}$} & \multirow{2}{*}{$\begin{array}{l}\text { Density } \\
\text { Scari- } \\
\text { dae }\end{array}$} & \multirow[b]{2}{*}{$\begin{array}{l}\text { Siga- } \\
\text { nidae }\end{array}$} & \multirow[b]{2}{*}{$\begin{array}{c}\text { Site } \\
\text { attached }\end{array}$} & \multirow[b]{2}{*}{ Total } & \multicolumn{4}{|c|}{ _ Biomass (kg) } & \multirow[t]{2}{*}{$\mathrm{r}^{2}$} \\
\hline & & & & & & & $\begin{array}{l}\text { Acanthu- } \\
\text { ridae }\end{array}$ & $\begin{array}{l}\text { Scari } \\
\text { dae }\end{array}$ & $\begin{array}{l}\text { Siga- } \\
\text { nidae }\end{array}$ & $\begin{array}{c}\text { Site } \\
\text { attached }\end{array}$ & \\
\hline Ulva consumed & $0.82^{* *}$ & $0.75^{*}$ & 0.28 & 0.19 & 0.05 & $0.92^{* * *}$ & $0.78^{* *}$ & 0.54 & 0.21 & 0.21 & 0.21 \\
\hline Relative algae accumulation & $0.80^{* *}$ & $0.70^{*}$ & 0.34 & 0.22 & 0.04 & $0.95^{* * *}$ & $0.75^{*}$ & $0.62^{*}$ & 0.26 & 0.26 & 0.17 \\
\hline Grazing pressure & 0.01 & 0.00 & $0.59^{*}$ & 0.16 & 0.22 & 0.04 & 0.01 & 0.10 & 0.16 & 0.16 & 0.14 \\
\hline
\end{tabular}

Floeter et al. (2005) showed that the density of herbivorous fish (and their richness) is positively correlated with sea surface temperatures, and suggested that temperature-related feeding and digestive processes may control latitudinal variation in their distribution. At a more local scale, Smith (2008) found a similar correlation along an $8^{\circ} \mathrm{C}$ temperature gradient, and suggested that lower temperature at depth may hinder herbivore excursions to deeper reefs. Temperature was also argued as explaining assumed low grazing rates on macroalgae in deep waters adjacent to the Florida Keys reef tract (Leichter et al. 2008). However, conclusions regarding the overriding influence of temperature have been dubbed 'premature' (Clements et al. (2009). Indeed, bathymetric gradients in herbivore abundance and richness in the northern Gulf of Aqaba 
are unlikely to be driven by temperature, since temperature stratification of the water column is limited to the summer months when the maximum difference between the shallow waters and $100 \mathrm{~m}$ is $\sim 4^{\circ} \mathrm{C}$ (Genin 2008).

The observed changes with depth in species richness and species composition add little insight as to what is causing the decrease in herbivore abundance. On the one hand, the unimodal distribution of species richness, with a peak at around 30 meters, is clearly not driven by the gradient in abundance. On the other hand, the bathymetric distribution of herbivore species richness seems to mimic that of other piscine functional groups at the study site which did not exhibit a similar monotonic decrease in abundance (Brokovich et al. 2008). Moreover, despite the obvious change in species composition across the depth gradient, we found no patterns in species attributes that may be indicative of the reason for the change.

Several unexplored (by us) explanations for the decrease in grazing pressure with depth are possible. We specifically need to address the nutritional ecology of herbivorous fish. For example, algal nutritional value, palatability and digestibility may decrease with depth. Zemke-White et al. (2002) have shown that grazers can detect small diel changes in algal nutritional value and can change their feeding rates to optimize foraging. There is some evidence for lower nutritional values in algae grown under lower levels of irradiance (Thompson et al. 1994, Rosen et al. 2000), as well as a lower storage lipid content and more structural lipid synthesis under lower light levels (Khotimchenko \& Yakovleva 2004). It is also possible, therefore, that algal nutritional values may decrease with depth and that herbivores distribute themselves accordingly.

Although algal palatability may play a smaller role than nutritional value in algal avoidance by herbivores (Clements et al. 2009), it remains to be tested whether depth has an effect on palatability. Panch et al. (2008) found no effect of light on the chemical defenses of algae, while Cronin \& Hay (1996) found that high levels of UV (as found in very shallow water) will decrease the abundance of some secondary metabolites, thus making shallow algae more susceptible to grazing (but see Macaya et al. 2005). The effects of irradiance and UV on algae and grazing will probably depend on algae species and the identity of the grazers (Molis et al. 2008). There is scarce data on algae digestibility under different abiotic conditions, and the subject needs more attention at a species specific level for both algae and herbivores.

Clements et al. (2009) conclude that predictive understanding of coral reef trophodynamics and the biogeographic distribution of marine herbivory must grow from analysis of the nutritional ecology. We make the same suggestion for the understanding of the bathymetric distribution of herbivorous fish. Attempts to understand the effect of herbivores on coral reef ecology and resilience (Ledlie et al. 2007) must consider the deeper reefs, along with their unique abiotic and biotic characteristics: low light intensity, limited spectrum (Mass et al. 2007, Lesser et al. 2009) and different assemblages of herbivorous fish species (Brokovich 2008, Brokovich et al. 2008).

Acknowledgements. The authors thank O. Ben Shafrut and D. Tobias for their help with the deep dives, T. Rivlin and M. Drey for their help with plate retrieval, Y. Sharon for his help with PAM measurements and analysis, and B. Kuguru for his light measurements data. We thank A. Alamaru for her review and important remarks and to $\mathrm{H}$. Choat and 3 anonymous reviewers for their insightful remarks. This study benefited from activities of the Israel National Monitoring Program at the Gulf of Eilat, supported by the Israel Ministry for Environmental Protection. We thank the Israel Nature and Park Authority for their cooperation. All Technical diving were performed with the assistance of the Marine Twilight-zone Research and Exploration center at the IUI (MTRX). This research was supported by the Israel Science Foundation (grant no. $740 / 04$ to S. K.)

\section{LITERATURE CITED}

Agegian CR, Abbott IA (1985) Deep water macroalgal communities: a comparison between Penguin Bank (Hawaii) and Johnston Atoll. In: Harmelin VM, Salv B (eds) Proc 5th Intern Coral Reef Congr, Tahiti, French Polynesia, p 47-50

Albert S, Udy J, Tibbetts I (2008) Responses of algal communities to gradients in herbivore biomass and water quality in Marovo Lagoon, Solomon Islands. Coral Reefs 27:73-82

Aponte NE, Ballantine DL (2001) Depth distribution of algal species on the deep insular fore reef at Lee Stocking Island, Bahamas. Deep-Sea Res I 48:2185-2194

Ateweberhan M, Bruggemann J, Breeman A (2006) Effects of extreme seasonality on community structure and functional group dynamics of coral reef algae in the southern Red Sea (Eritrea). Coral Reefs 25:391-406

Beer S, Vilenkin B, Weil A, Veste M, Susel L, Eshel A (1998) Measuring photosynthetic rates in seagrasses by pulse amplitude modulated (PAM) fluoremetry. Mar Ecol Prog Ser 174:293-300

Benayahu Y, Loya Y (1977) Seasonal occurrence of benthicalgae communities and grazing regulation by sea urchins at the coral reefs of Eilat, Red Sea. Proc 3rd Int Coral Reef Symp 1:383-389

Brokovich E (2008) Coral reef fish assemblages in the upper twilight zone $(<65 \mathrm{~m})$. In: Por FD (ed) Aqaba-Eilat, the Improbable Gulf Environment, Biodiversity and Preservation. Magnes Press, Jerusalem, p 255-266

Brokovich E, Einbinder S, Kark S, Shashar N, Kiflawi M (2007) A deep nursery for juveniles of the zebra angelfish Genicanthus caudovittatus. Environ Biol Fishes 80:1-6

> Brokovich E, Einbinder S, Shashar N, Kiflawi M, Kark S (2008) Descending to the twilight-zone: changes in coral reef fish assemblages along a depth gradient down to 65 m. Mar Ecol Prog Ser 371:253-262

Burkepile DE, Hay ME (2006) Herbivore vs. nutrient control of marine primary producers: context-dependent effects. Ecology 87:3128-3139 
Cade BS, Noon BR (2003) A gentle introduction to quantile regression for ecologists. Front Ecol Environ 1:412-420

Cade BS, Terrell JW, Schroeder RL (1999) Estimating effects of limiting factors with regression quantiles. Ecology 80: 311-323

> Carpenter RC (1986) Partitioning herbivory and its effects on coral reef algal communities. Ecol Monogr 56:345-364

Choat JH (1991) The biology of herbivorous fishes on coral reefs. In: Sale PF (ed) The ecology of fishes on coral reefs. Academic, San Diego, CA, pp 120-155

Choat JH, Robbins WD, Clements KD (2004) The trophic status of herbivorous fishes on coral reefs. Mar Biol 145: $445-454$

> Clements KD, Raubenheimer D, Choat JH (2009) Nutritional ecology of marine herbivorous fishes: ten years on. Funct Ecol 23:79-92

Colin P, Devaney D, Hillis-Colinvaux L, Suchanek T, Harrison JI (1986) Geology and biological zonation of the reef slope, 50-360 m depth at Enewetak Atoll, Marshall Islands. Bull Mar Sci 38:111-128

Colwell RK (2005) EstimateS: statistical estimation of species richness and shared species from samples. http://purl. oclc.org/estimates

Cooper DC (1973) Enhancement of net primary productivity by herbivore grazing in aquatic laboratory microcosms. Limnol Oceanogr 18:31-37

Cronin G, Hay ME (1996) Susceptibility to herbivores depends on recent history of both the plant and animal. Ecology 77:1531-1543

- Floeter SR, Behrens MD, Ferreira CEL, Paddack MJ, Horn $\mathrm{MH}$ (2005) Geographical gradients of marine herbivorous fishes: patterns and processes. Mar Biol 147: 1435-1447

Fox RJ, Bellwood DR (2007) Quantifying herbivory across a coral reef depth gradient. Mar Ecol Prog Ser 339:49-59

Fricke HW, Schumacher H (1983) The depth limit of Red Sea stony corals: an ecophysiological problem (a deep diving survey by submersible). Mar Biol 4:163-194

Froese R, Pauly D (2007) FishBase. World Wide Web electronic publication, www.fishbase.org

Genin A (2008) The physical setting of the Gulf of Aqaba: an explanation for a unique occurrence of tropical communities in the subtropics. In: Por FD (ed) Aqaba-Eilat, the Improbable Gulf environment, biodiversity and preservation. Magnes Press, Jerusalem, p 15-20

Genin A, Silverman J (2003) Israel National Monitoring Program of the Gulf of Eilat annual report 2003 (In Hebrew, with English abstract and figure legends)

Genin A, Lazar B, Brenner S (1995) Vertical mixing and coral death in the Red Sea following the eruption of Mount Pinatubo. Nature 377:507-510

Gilmartin M (1960) The ecological distribution of the deep water algae of Eniwetok Atoll. Ecology 41:210-221

Gobler CJ, Thibault DB, Davis TW, Curran PB, Peterson BJ, Liddle LB (2006) Algal assemblages associated with Stegastes sp territories on Indo-Pacific coral reefs: Characterization of diversity and controls on growth. J Exp Mar Biol Ecol 336:135-145

Gotelli NJ, Colwell RK (2001) Quantifying biodiversity: Procedures and pitfalls in the measurement and comparison of species richness. Ecol Lett 4:379-391

- Hillis-Colinvaux L (1986) Halimeda growth and diversity on the deep fore-reef of Enewetak Atoll. Coral Reefs 5: $19-21$

Hixon MA, Brostoff WN (1996) Succession and herbivory: effects of differential fish grazing on Hawaiian coral-reef algae. Ecol Monogr 66:67-90
Hughes TP, Rodrigues MJ, Bellwood DR, Ceccarelli D and others (2007) Phase shifts, herbivory, and the resilience of coral reefs to climate change. Curr Biol 17:360-365

Jackson JBC, Kirby MX, Berger WH, Bjorndal KA and others (2001) Historical overfishing and the recent collapse of coastal ecosystems. Science 293:629-638

Khalaf MA, Disi AM (1997) Fishes of the Gulf of Aqaba. The Marine Science Station, Aqaba

Khalaf MA, Kochzius M (2002) Changes in trophic community structure of shore fishes at an industrial site in the Gulf of Aqaba, Red Sea. Mar Ecol Prog Ser 239:287-299

Khotimchenko SV, Yakovleva IM (2004) Effect of solar irradiance on lipids of the green alga Ulva fenestrata Postels et Ruprecht. Bot Mar 47:395-401

Kuffner IB, Walters LJ, Becerro MA, Paul VJ, Ritson-Williams R, Beach KS (2006) Inhibition of coral recruitment by macroalgae and cyanobacteria. Mar Ecol Prog Ser 323: $107-117$

Ledlie MH, Graham NAJ, Bythell JC, Wilson SK, Jennings S, Polunin NVC, Hardcastle J (2007) Phase shifts and the role of herbivory in the resilience of coral reefs. Coral Reefs 26: 641-653

> Leichter JJ, Stokes MD, Genovese SJ (2008) Deep water macroalgal communities adjacent to the Florida Keys reef tract. Mar Ecol Prog Ser 356:123-138

Lesser MP, Slattery M, Leichter JJ (2009) Ecology of mesophotic coral reefs. J Exp Mar Biol Ecol 375:1-8

Liddell WD, Sharon LO (1988) Hard substrata community patterns, 1-120 m, North Jamaica. Palaios 3:413-423

Lindell D, Post AF (1995) Ultraphytoplankton succession is triggered by deep winter mixing in the Gulf of Aqaba (Eilat), Red Sea. Limnol Oceanogr 40:1130-1141

Littler MM, Littler DS, Blair SM, Norris JN (1985) Deepest known plant life discovered on an uncharted seamount. Science 227:57-59

> Macaya EC, Rothäusler E, Thiel M, Molis M, Wahl M (2005) Induction of defenses and within-alga variation of palatability in two brown algae from the northern-central coast of Chile: effects of mesograzers and UV radiation. J Exp Mar Biol Ecol 325:214-227

- Markager S, Sand-Jensen K (1992) Light requirements and depth zonation of marine macroalgae. Mar Ecol Prog Ser 88:83-92

Mass T, Einbinder S, Brokovich E, Shashar N, Vago R, Erez J, Dubinsky Z (2007) Photoacclimation of Stylophora pistillata to light extremes: metabolism and calcification. Mar Ecol Prog Ser 334:93-102

- McClanahan TR, Hendrick V, Rodrigues MJ, Polunin NVC (1999a) Varying responses of herbivorous and invertebrate-feeding fishes to macroalgal reduction on a coral reef. Coral Reefs 18:195

McClanahan TR, Muthiga NA, Kamukuru AT, Machano H, Kiambo RW (1999b) The effects of marine parks and fishing on coral reefs of northern Tanzania. Biol Conserv 89: 161-182

McClanahan TR, McField M, Huitric M, Bergman K and others (2001) Responses of algae, corals and fish to the reduction of macroalgae in fished and unfished patch reefs of Glovers Reef Atoll, Belize. Coral Reefs 19:367-379

McCook LJ, Jompa J, Diaz-Pulido G (2001) Competition between corals and algae on coral reefs: a review of evidence and mechanisms. Coral Reefs 19:400-417

Miller MW, Hay ME (1998) Effects of fish predation and seaweed competition on the survival and growth of corals. Oecologia 113:231-238

Miller MW, Hay ME, Miller SL, Malone D, Sotka EE, Szmant AM (1999) Effects of nutrients versus herbivores on reef 
algae: A new method for manipulating nutrients on coral reefs. Limnol Oceanogr 44:1847-1861

Molis M, Koerner J, Ko YW, Kim JH (2008) Specificity of inducible seaweed anti-herbivory defences depends on identity of macroalgae and herbivores. Mar Ecol Prog Ser 354:97-105

Morrison D (1988) Comparing fish and urchin grazing in shallow and deeper coral reef algal communities. Ecology 69:1367-1382

Pacheco MAW, McIntyre DO, Linton TK (2005) Integrating chemical and biological criteria. Environ Toxicol Chem 24: 2983-2991

Pansch C, Gomez I, Rothäusler E, Veliz K, Thiel M (2008) Species-specific defense strategies of vegetative versus reproductive blades of the Pacific kelps Lessonia nigrescens and Macrocystis integrifolia. Mar Biol 155:51-62

Parsons TR, Maita Y, Lalli CM (1984) A manual of chemical and biological methods for seawater analysis. Pergamon Press, Exeter

Platt T, Gallegos CL, Harrison WG (1980) Photoinhibition of photosynthesis in natural assemblages of marine phytoplankton. J Mar Res 38:687-701

Ralph PJ, Gademann R (2005) Rapid light curves: A powerful tool to assess photosynthetic activity. Aquat Bot 82:222-237

Randall JE (1983) Red Sea reef fishes. IMMEL Publishing, London Rosen G, Langdon CJ, Evans F (2000) The nutritional value of Palmaria mollis cultured under different light intensities and water exchange rates for juvenile red abalone Haliotis rufescens. Aquaculture 185:121-136

Editorial responsibility: John Choat,

Townsville, Australia
Russ GR (2003) Grazer biomass correlates more strongly with production than with biomass of algal turfs on a coral reef. Coral Reefs 22:63-67

Shaked Y, Genin A (2009) Israel National Monitoring Program of the Gulf of Eilat Annual Report 2008 (In Hebrew, with English abstract and figure legends)

Smith T (2008) Temperature effects on herbivory for an IndoPacific parrotfish in Panamá: implications for coral-algal competition. Coral Reefs 27:397-405

Smith J, Smith C, Hunter C (2001) An experimental analysis of the effects of herbivory and nutrient enrichment on benthic community dynamics on a Hawaiian reef. Coral Reefs 19:332-342

> Thompson PA, Guo MX, Harrison PJ (1994) Influence of irradiance on the nutritional value of two phytoplankton species fed to larval Japanese scallops (Patinopecten yessoensis). Mar Biol 119:89-97

Van den Hoek C, Breeman AM, Bak RPM, Van Buurt G (1978) The distribution of algae, corals and gorgonians in relation to depth, light attenuation, water movement and grazing pressure in the fringing coral reef of Curaçao, Netherlands Antilles. Aquat Bot 5:1-46

Veron JEN (2000) Corals of the world. Australian Institute of Marine Science, Townsville

Vroom PS, Page KN, Kenyon JC, Brainard RE (2006) Algaedominated reefs. Am Sci 94:430-437

> Zemke-White LW, Choat J, Clements K (2002) A re-evaluation of the diel feeding hypothesis for marine herbivorous fishes. Mar Biol 141:571-579

Submitted: May 2, 2009; Accepted: October 5, 2009

Proofs received from author(s): January 21, 2010 